\title{
Upregulation of Parkin in Endophilin Mutant Mice
}

\author{
Mian Cao, ${ }^{1}$ Ira Milosevic, ${ }^{1,2}$ Silvia Giovedi, ${ }^{1,3}$ and Pietro De Camilli ${ }^{1}$ \\ ${ }^{1}$ Department of Cell Biology, Howard Hughes Medical Institute and Program in Cellular Neuroscience, Neurodegeneration and Repair, Yale University \\ School of Medicine, New Haven, Connecticut 06510, ${ }^{2}$ European Neuroscience Institute (ENI), 37077 Göttingen, Germany, and ${ }^{3}$ Department of Experimental \\ Medicine, University of Genoa, 16132 Genoa, Italy
}

Several proteins encoded by PD genes are implicated in synaptic vesicle traffic. Endophilin, a key factor in the endocytosis of synaptic vesicles, was shown to bind to, and be ubiquitinated by, the PD-linked E3 ubiquitin ligase Parkin. Here we report that Parkin's level is specifically upregulated in brain and fibroblasts of endophilin mutant mice due to increased transcriptional regulation. Studies of transfected HEK293T cells show that Parkin ubiquitinates not only endophilin, but also its major binding partners, dynamin and synaptojanin 1 . These results converge with the recently reported functional relationship of endophilin to the PD gene LRRK2 and with the identification of a PD-linked synaptojanin 1 mutation, in providing evidence for a link between PD and endocytosis genes.

Key words: Parkinson; Parkinsonism; dynamin; clathrin; auxilin

\section{Introduction}

Synaptic transmission relies on the release of neurotransmitters via the fusion of synaptic vesicles with plasma membrane. Rapid endocytosis and recycling of synaptic vesicles allow synapses to function even during high-frequency stimulation. Endophilin, the collective names of endophilin 1,2, and 3 in mammals, has an important role in this process as an adaptor that recruits other endocytic factors to endocytic sites. Its N-terminal BAR domain binds high-curvature membranes (the neck of endocytic pits), while the two major binding partners of its $\mathrm{SH} 3$ domain are dynamin, a GTPase implicated in the fission of the bud neck, and synaptojanin 1, the phosphatidylinositol-4,5-bisphosphate $\left[\mathrm{PI}(4,5) \mathrm{P}_{2}\right]$ phosphatase required for rapid clathrin uncoating after fission (de Heuvel et al., 1997; Ringstad et al., 1997; Cremona et al., 1999). The interaction of endophilin with synaptojanin is particularly important as the absence of endophilin or of synaptojanin produces strikingly similar phenotypes in worms, flies, and mice (Schuske et al., 2003; Verstreken et al., 2003; Hayashi et al., 2008; Milosevic et al., 2011). In mice, the absence of the three endophilins or of synaptojanin 1 results in perinatal lethality and in a dramatic accumulation of clathrin-coated vesicles at synapses (Hayashi et al., 2008; Milosevic et al., 2011).

Received April 28, 2014; revised 0ct. 27, 2014; accepted Oct. 30, 2014.

Author contributions: M.C., I.M., S.G., and P.D.C. designed research; M.C., I.M., and S.G. performed research;M.C., I.M., S.G., and P.D.C. analyzed data; M.C. and P.D.C. wrote the paper.

This work was supported in part by the grants from the National Institutes of Health (R37NS03625), the Ellison Foundation, and the Michael J. Fox Foundation (No. 8954) to P.D.C.; and a postdoctoral fellowship from the American Parkinson disease Association to M.C. We thank Lijuan Liu, Louise Lucast, Heather Czapla, Melanie König, and Frank Wilson for superb technical assistance and Mirko Messa for the gift of purified GST proteins. We are also grateful to Dr. Lois Weisman (University of Michigan) for the gift of Vac14 brain tissues and antibody and to Dr. Jun Xia (Hong Kong University of Science and Technology) for the gift of myc-Parkin plasmid.

The authors declare no competing financial interests.

Correspondence should be addressed to Pietro De Camilli, Department of Cell Biology, Howard Hughes Medical Institute and Program in Cellular Neuroscience, Neurodegeneration and Repair, Yale University School of Medicine, New Haven, CT 06510. E-mail: pietro.decamilli@yale.edu.

DOI:10.1523/JNEUROSCI.1710-14.2014

Copyright $\odot 2014$ the authors $\quad 0270-6474 / 14 / 3416544-06 \$ 15.00 / 0$
Partial loss of endophilin [endophilin 1 and 2 double KO (DKO) mice] is compatible with early postnatal life but results in neurodegeneration and death within 3 weeks (Milosevic et al., 2011).

Parkin is an E3 ubiquitin ligase whose mutations lead to autosomal recessive juvenile-onset PD (Shimura et al., 2000). Parkin comprises an N-terminal ubiquitin-like domain (UBL), a central RING0 domain, and a C-terminal RING1-IBR-RING2 domain. Parkin can catalyze both K48-linked poly-ubiquitination for proteasome-mediated degradation and K63-linked polyubiquitination and mono-ubiquitination for the regulation of protein-protein interactions (Dawson and Dawson, 2010). Several synaptic proteins were identified as Parkin's substrates and/or interactors. These include the synaptic vesicle-associated proteins CDCrel-1 and synaptotagmin XI, which are degraded through Parkin-mediated poly-ubiquitination (Zhang et al., 2000; Huynh et al., 2003), and CASK, PICK1, and Eps15, which are modified through Parkin-dependent mono-ubiquitination (Fallon et al., 2002, 2006; Joch et al., 2007). They also include endophilin, which interacts with the UBL domain of Parkin via its $\mathrm{SH} 3$ domain and is ubiquitinated by Parkin. This interaction is regulated by phosphorylation, suggesting that it may be part of a regulatory mechanism (Trempe et al., 2009). These findings are of significant interest considering that biochemical and genetic interactions have been observed between endophilin and LRRK2, another protein implicated in PD (Matta et al., 2012), and that a mutation in the preferred endophilin partner, synaptojanin 1, was observed in PD patients (Krebs et al., 2013; Quadri et al., 2013; Olgiati et al., 2014).

Here we show that Parkin's protein level is specifically upregulated in brain tissue and cells of mice lacking endophilin. Furthermore, we show that not only endophilin itself, but also its major binding partners, can be mono-ubiquitinated by Parkin.

\section{Materials and Methods}

Animals and tissues. Endophilin 1 and $2 \mathrm{DKO}$ and endophilin triple $\mathrm{KO}$ (TKO) mice were described previously (Milosevic et al., 2011). Parkin KO mice were obtained from The Jackson Laboratory (006582, 


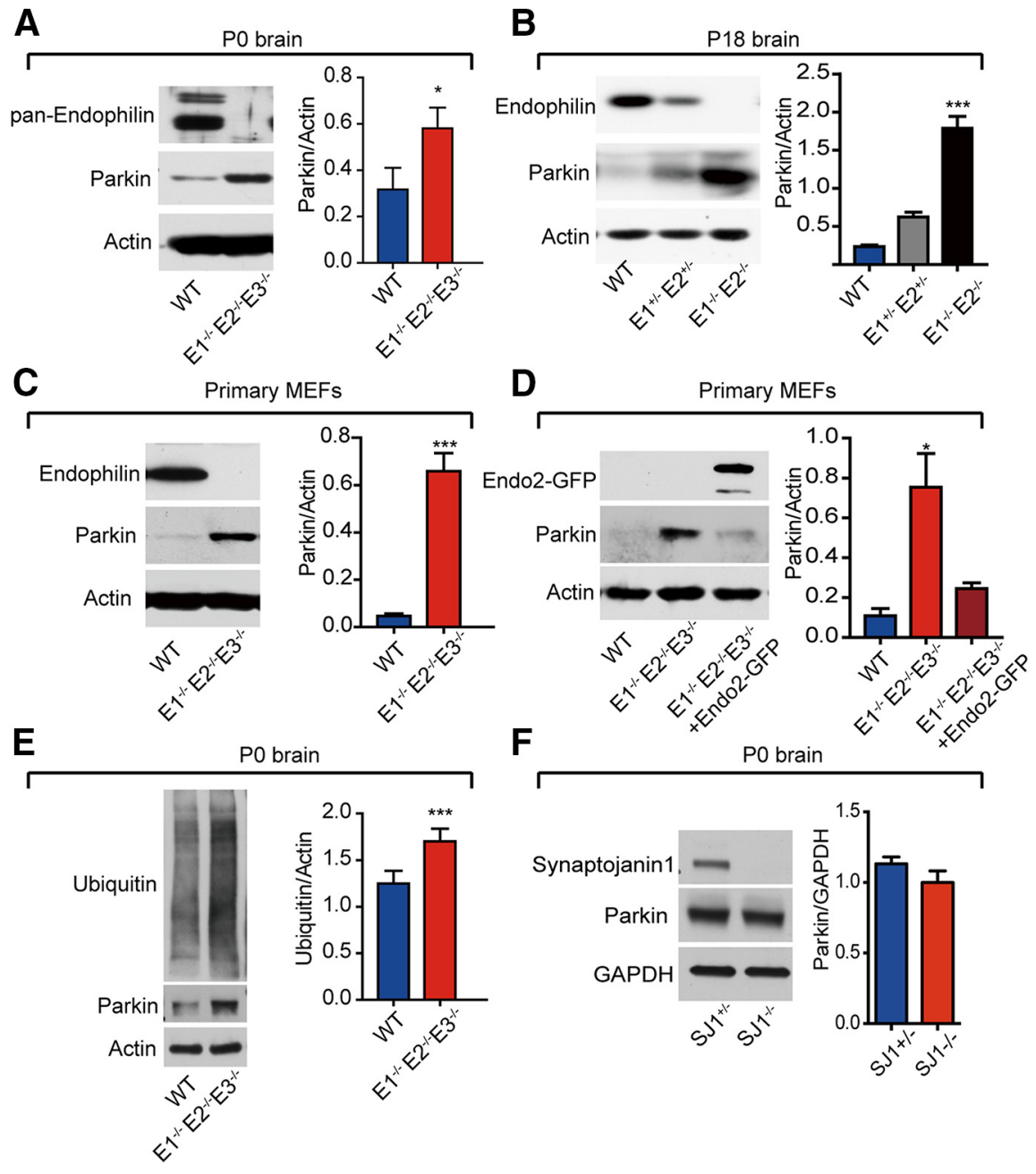

Figure 1. Protein levels of Parkin are specifically upregulated in endophilin-deficient brain and cells. $\boldsymbol{A}$, Western blot (left) and quantification (right) showing that Parkin level is increased in the brain of newborn endophilin TKO mice. $\boldsymbol{B}$, The increase in Parkin levels scales with the loss of endophilin gene alleles as shown by the analysis of brains of endophilin 1 and 2 DHt and DKO P18 mice. C, Parkin level is also robustly increased in MEFs derived from endophilin TKO mice. D, Overexpression of endophilin2-GFP "rescues" the increase in Parkin observed in endophilin TKO MEFs. $E$, An overall increase in protein ubiquitination is observed in endophilin TKO brains. $\boldsymbol{F}$, Parkin level is not changed in synaptojanin $1 \mathrm{KO}$ newborn brains. Anti-actin and anti-GAPDH Western blots are used as the loading control. Corresponding quantification of Western blots are shown on the right for each part. ${ }^{*} p<0.05$, ${ }^{* * *} p<$ 0.001 , Student's $t$ test. Error bar represents SEM.

B6.129S4-Park $2<\operatorname{tm} 1$ Shn $>/ J)$. Mice of either sex were used for this study. Animal care and use was performed in accordance with our institutional guidelines. Frozen brains of newborn (P0) Vac14 KO mice were the gift from Dr. Lois Weisman at University of Michigan.

Plasmids. The sources of cDNAs were as follows: clathrin light chain (CLC)-GFP was a gift from James Keen (Thomas Jefferson University, Philadelphia, PA); myc-Parkin was a gift from Jun Xia (Hong Kong University of Science and Technology); and endophilin1-GFP, endophilin2-GFP, endophilin3-GFP, GFP-synaptojanin1, dynamin 1-GFP, and HA-ubiquitin were from our lab.

Antibodies. Primary antibodies used in this study were as follows: anti-pan-endophilin, anti-synaptojanin1, anti-dynamin3, antiamphiphysin1, anti-clathrin heavy chain, anti-Fig4, anti-auxilin, anti-PIPK1 $\gamma$ (our lab), anti-Parkin (\#4211; Cell Signaling Technology), anti-actin (ICN Biomedicals), anti-pan-dynamin (\#610245; BD Transduction Laboratories), anti-AP-2 (AP50; BD Transduction Laboratories), anti-dynamin1 (\#1851-1; Epitomics), anti-CLC (AB9884; Millipore), anti-Uch-L1 (AB1761; Millipore), anti-Nedd4 (\#07049; Millipore), anti-ubiquitin (FK2; Enzo and Covance), anti-HA-peroxidase (3F10; Roche), anti-GFP (ab290; Abcam), anti-myc (9E10; Santa Cruz Biotechnology), anti-Vac14 (a gift from Dr. Lois Weisman, University of Michigan,
Ann Arbor, MI), anti-CD2AP, and anti-CIN85 (a gift from Andrey Shaw, Washington University, St. Louis, MO).

Biochemical analysis. Postnuclear supernatant of brain tissue for the analysis of protein levels was obtained by homogenization of mouse brain in buffer containing $20 \mathrm{~mm}$ Tris, pH 7.4, $150 \mathrm{~mm} \mathrm{NaCl}$, and 2 mm EDTA supplemented with protease inhibitors and subsequent centrifugation at $700 \mathrm{~g}$ for $10 \mathrm{~min}$. Triton X-100 extracts of brain and cultured cells were generated using a buffer containing $20 \mathrm{~mm}$ HEPES, pH 7.9, $150 \mathrm{~mm} \mathrm{NaCl}$, and 1\% Triton $\mathrm{X}-100$ supplemented with protease inhibitors. SDS-PAGE and Western blotting were performed by standard procedure. For GST pulldowns, Triton X-100 extracts of mouse brain tissue or of HeLa cells expressing myc-Parkin were incubated with GST or GST fusion proteins (SH3 domains of endophilin1, 2, and 3) immobilized on glutathione-Sepharose beads, washed, and eluted with SDS sample buffer. For immunoprecipitation, HEK293T cell lysates were incubated for $2 \mathrm{~h}$ at $4^{\circ} \mathrm{C}$ with anti-GFP antibody-coupled Protein G beads, washed with lysis buffer, and eluted with SDS sample buffer.

Cell culture and transfection. HeLa, HEK293T, and primary mouse embryonic fibroblasts (MEFs) were cultured in DMEM containing $10 \% \mathrm{FBS}$ at $37^{\circ} \mathrm{C}$ and $5 \% \mathrm{CO}_{2}$. Transfection of plasmids was performed with Lipofectamine 2000 (Life Technologies) in HeLa and HEK293T cells and with Amaxa-based electroporation (Lonza) in MEFs.

Real-time qPCR. Total RNA was extracted from brains and primary MEFs using the RNeasy Mini Kit (Qiagen). cDNA was synthesized with the iScript cDNA synthesis kit (Bio-Rad) and the resulting cDNA was subjected to real-time qPCR with the iTaq Universal SYBR Green Supermix (Bio-Rad) according to manufacturer's instructions. Data were normalized to the internal control, the reference gene actin, or HPRT. Primers used were as follows: mouse Parkin Fw: gagcttccgaatcacctgac; mouse Parkin Rv: ccctccagatgcatttgttt; mouse endophilin $2 \mathrm{Fw}$ : tggcaaggaactaggtggagag; mouse endophilin 2 Rv: cctccaatttcttcaggtggtg; mouse actin Fw: gtgacgttgacatccgtaaaga; mouse actin Rv: gccggactcatcgtactcc; mouse HPRT Fw: cctcctcagaccgcttttt; mouse HPRT Rv: aacctggttcatcatcgctaa.

Statistics. Data are reported as mean \pm SEM. Student's $t$ test (unpaired) was performed for comparisons. Values of $p<0.05$ were used as the criterion for statistical significance.

\section{Results}

\section{Parkin level is specifically increased in endophilin KO brain} and MEFs

It was previously reported that the levels of several synaptic vesicles and nerve terminal proteins are lower in the brain of newborn endophilin 1, 2, and 3 TKO mice (Milosevic et al., 2011). Proteins whose levels were decreased included synaptojanin 1, a direct endophilin interactor (Milosevic et al., 2011), while the levels of dynamin (Milosevic et al., 2011), CD2AP, and CIN85 (data not shown) were unchanged. Surprisingly, the level of Parkin, also a direct interactor, was strongly elevated (Fig. 1A). Parkin was also present at a higher concentration relative to WT in 
P18 brains of endophilin 1 and 2 double heterozygous (DHt) mice (which do not exhibit a major phenotype) and more robustly in P18 brains of endophilin 1 and $2 \mathrm{DKO}$ mice (Fig. 1B). As the comparison between endophilin 1 and $2 \mathrm{DHt}$ and endophilin 1 and 2 DKO was performed with animals from the same litter, variability between different litters or genetic backgrounds was ruled out. Thus, elevation of Parkin's level scales with the reduction of endophilin level (Fig. 1B). Changes of Parkin in the absence of endophilin were not specific of brain, where endophilin loss of function results in neurodegeneration (Milosevic et al., 2011), as Parkin was also increased relative to WT in primary MEFs derived from endophilin TKO mice (Fig. 1C). Overexpression of endophilin 2-GFP (endophilin 2 is the major endophilin in non-neuronal cells) in endophilin TKO MEFs significantly rescued this upregulation (Fig. 1D). Since Parkin is an E3 ubiquitin ligase, we also examined the ubiquitination state of the total proteome in newborn endophilin TKO brains and found that it was significantly increased (Fig. $1 E$ ).

In contrast to the elevation of Parkin, the levels of two other enzymes of ubiquitin metabolism, Nedd4 (another E3 ubiquitin ligase) and UchL1 (a de-ubiquitinating enzyme expressed in nerve system also implicated in PD), were present at normal concentrations in endophilin TKO brains (data not shown).

The function of endophilin is closely interconnected with the function of synaptojanin 1, as (1) these two proteins bind to each other; (2) the presence of endophilin helps target and stabilize synaptojanin 1; and (3) the absence of endophilin or of synaptojanin produces striking similar phenotypes in worms, flies, and mice (Schuske et al., 2003; Verstreken et al., 2003; Hayashi et al., 2008; Milosevic et al., 2011). However, Parkin level was unchanged in these brains (Fig. $1 F$ ), indicating that the increase in Parkin produced by the partial or total absence of endophilin is a specific effect. No change of Parkin expression was observed in brains of several other mutant mice tested. These included the following: (1) dynamin $1 \mathrm{KO}$ mice, which exhibit endocytic defects different from those of endophilin TKO mice but similarly severe (Ferguson et al., 2007); (2) KO mice for Vac14 and for the inositol phosphatase Fig4, two models of neurodegeneration resulting from abnormal PI(3,5) $\mathrm{P}_{2}$ metabolism (Chow et al., 2007; Zhang et al., 2007); (3) KO mice for auxilin, a protein, which like synaptojanin, has an impact on clathrin uncoating (Yim et al., 2010); and (4) KO mice for PIPK1 $\gamma$, the major PI $(4,5) \mathrm{P}_{2}$ synthesizing enzyme at synapses, whose absence produced $\mathrm{PI}(4,5) \mathrm{P}_{2}$ changes opposite those produced by the lack of synaptojanin 1 (Di Paolo et al., 2004; data not shown).

Analysis of Parkin mRNA by RT-PCR revealed a significant, robust increase in endophilin TKO newborn brains relative to WT controls (Fig. 2A,B). A similar upregulation of Parkin mRNA level was observed in endophilin1 and 2 DKO brains (P15-P21; Fig. 2C,D) and in primary MEFs derived from endophilin TKO mice (Fig. 2E,F). In contrast, the mRNA level of Parkin in synaptojanin $1 \mathrm{KO}$ newborn brains was not significantly different from controls (Fig. 2G). Together, these data indicate that the increased level of Parkin in endophilin mutant mice is due to enhanced gene transcription.

Mutations of Parkin, most of which lead to impaired E3 ligase activity, are responsible for autosomal recessive juvenile-onset PD, suggesting that loss of function of Parkin causes neurodegeneration. However, Parkin KO mice are grossly normal, without any obvious neurodegenerative sign (e.g., loss of dopaminergic neurons; Goldberg et al., 2003) and expression levels of endophilin and several other endocytic proteins in Parkin
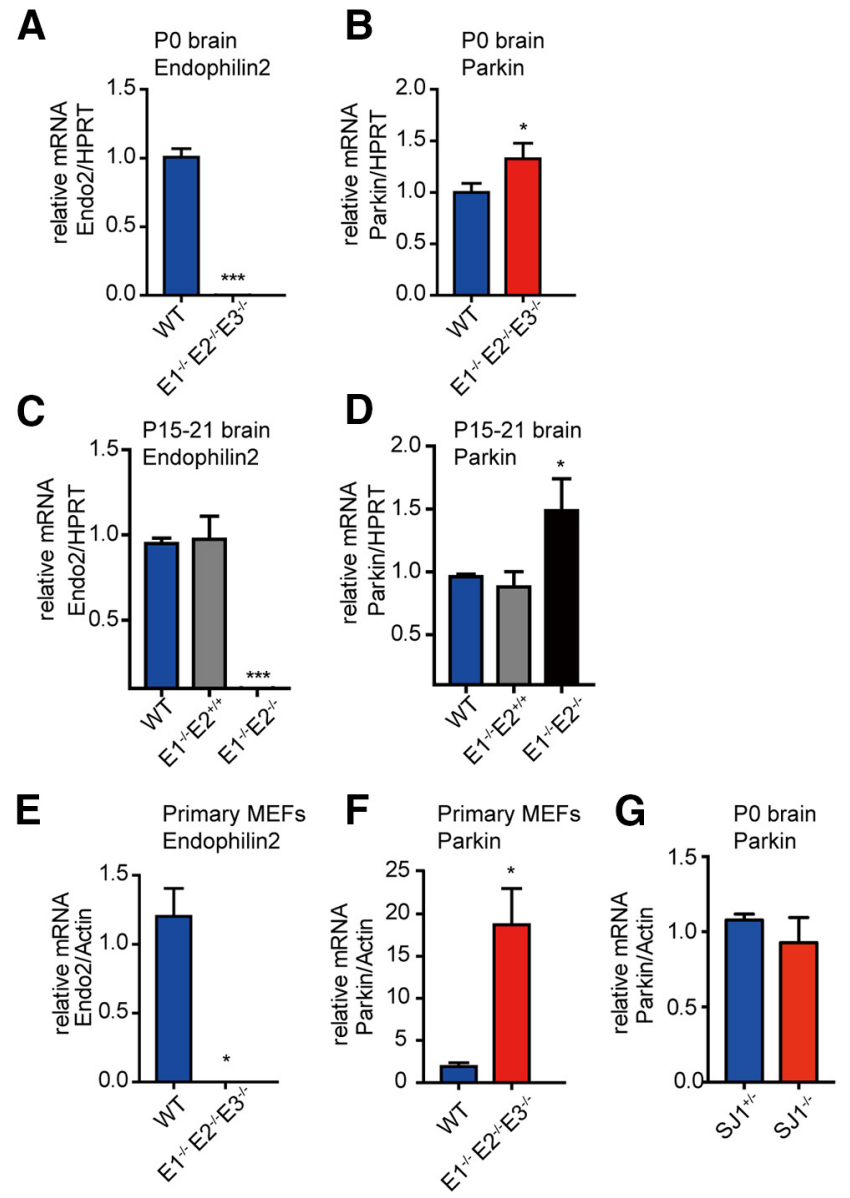

Figure 2. The increase in Parkin observed in endophilin-deficient brain and MEFs is due to enhanced transcription. $\boldsymbol{A}, \boldsymbol{B}$, Levels of endophilin 2 and Parkin mRNA were analyzed by qRTPCR on total RNA extracted from endophilin TKO PO brain. WT (C57BL/6) mouse brains were used as controls and HPRT was used as internal control gene. Parkin mRNA is significantly increased in endophilin TKO PO brain. C, D, qRT-PCR data show that Parkin mRNA is also upregulated in endophilin 1 and 2 DKO brains (P15-P22). Brains of littermates (E1 ${ }^{-/-} E 2^{+/+}$) and WT (C57BL/6) mice were used as controls. HPRT was used as an internal control gene. $\boldsymbol{E}, \boldsymbol{F}$, Parkin mRNA level is also strikingly increased in MEFs derived from endophilin TKO mice. $\boldsymbol{G}$, Parkin mRNA level is not changed in synaptojanin $1 \mathrm{~K} 0$ newborn brains. Actin was used as an internal control gene. ${ }^{*} p<0.05,{ }^{* * *} p<0.001$, Student's $t$ test. Error bar represents SEM.

KO newborn brains were not different from controls (data not shown; Trempe et al., 2009).

\section{Parkin-mediated ubiquitination of endophilin, dynamin, and synaptojanin 1}

Consistent with previous observations (Trempe et al., 2009), GST pull-downs from HeLa cells expressing myc-Parkin using the GST-SH3 domains of endophilin 1, 2, and 3 as bait resulted in the enrichment of myc-Parkin with stronger binding to endophilin 1 and 3 relative to endophilin 2 (Fig. $3 A$, bottom). Endogenous dynamin 2, used as positive control, also strongly interacted with the SH3 domains of all three endophilins (Fig. $3 A$, top). Similar results were obtained by performing GST pull-downs from mouse brain lysate (Fig. 3B). Likewise, as reported (Trempe et al., 2009), an interaction between endophilin and Parkin in vivo was supported by a specific enrichment, albeit modest, of myc-Parkin in anti-GFP immunoprecipitates generated from cells expressing myc-Parkin and GFP-endophilin 1, 2, or 3 (GFP tag at the C terminus; Fig. 3C).

Endophilin was shown to be mono-ubiquitinated by Parkin under cell-free conditions (Trempe et al., 2009). We investigated 


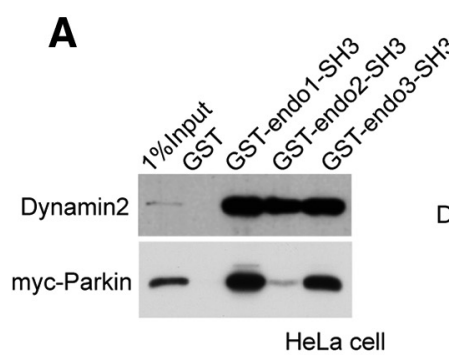

D

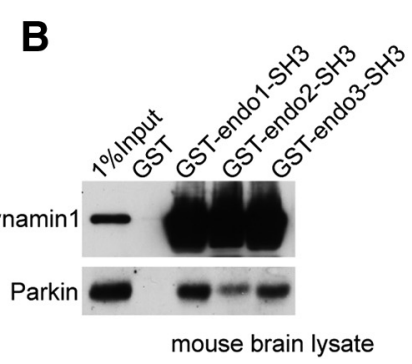

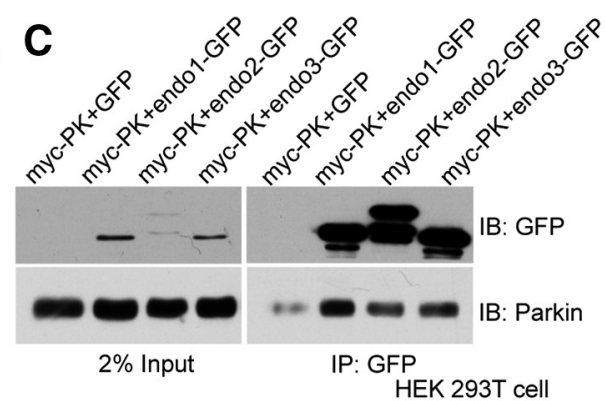

HEK 293T cell

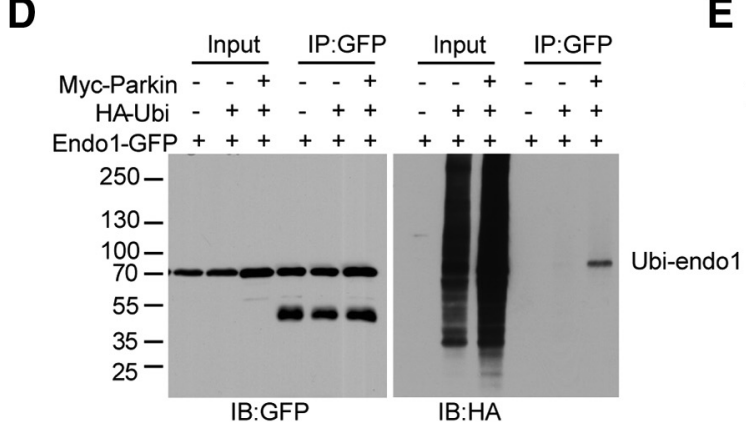

$\mathbf{E}$

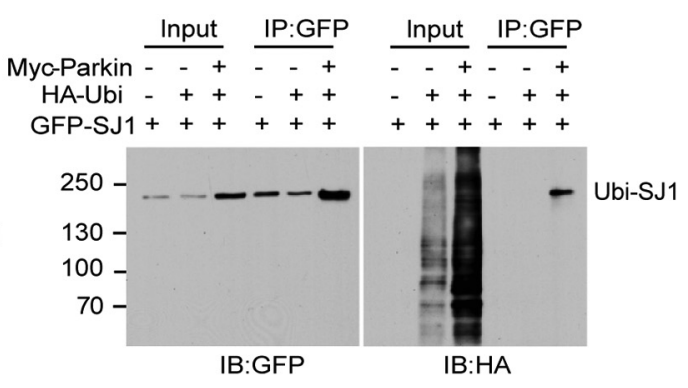

$\mathbf{F}$

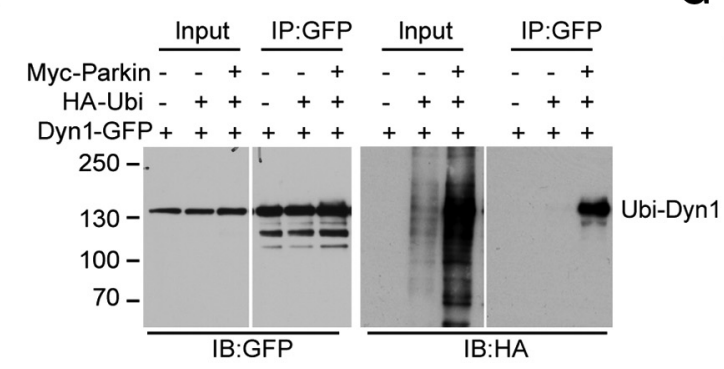

G

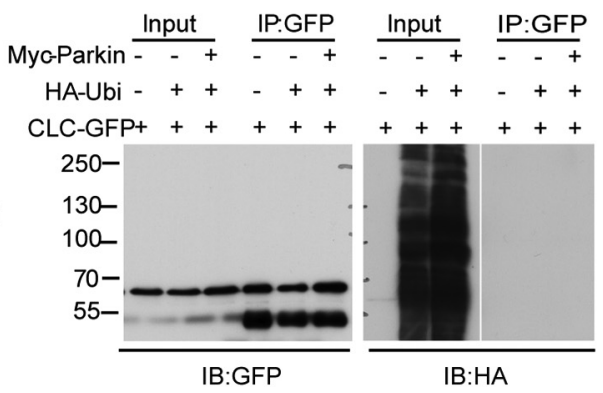

Figure 3. Parkin-mediated ubiquitination of endophilin and its binding partners. A, GST pull-downs from HeLa cells expressing myc-Parkin using the SH 3 domains of endophilin 1,2 , and 3 as bait, demonstrating the interaction between endophilin (primarily endophilin 1 and 3) and Parkin. The affinity-purified material was analyzed by Western blotting for the myc epitope and for endogenous dynamin 2 as a positive control. B, GST pull-downs from mouse brain lysates using the SH3 domain of endophilin 1, 2, and 3 as bait. Dynamin 1 was used as positive control. C, HEK293T expressing myc-Parkin (myc-PK) and C-terminally GFP tagged endophilin 1, 2, and 3 was subjected to immunoprecipitation (IP) with anti-GFP antibody. Western blots (IB) of the immunoprecipitates for GFP and for Parkin are shown. D-G, Analysis of in vivo ubiquitination. GFP fusions of endophilin 1 (End01-GFP), synaptojanin 1 (GFP-SJ1), dynamin 1 (Dyn1-GFP), and CLC were independently coexpressed with HA-ubiquitin (HA-Ubi) in the presence or absence of coexpressed myc-Parkin. Cell extracts were subjected to immunoprecipitation with anti-GFP antibody and protein ubiquitination was detected by anti HA Western blotting. Endophilin, synaptojanin, and dynamin, but not CLC, were mono-ubiquitinated in the presence of Parkin.

whether endophilin could be ubiquitinated in the context of a living cell by examining its ubiquitination in HEK293T cells expressing endophilin1-GFP, HA-ubiquitin, and myc-Parkin in the combinations shown in Figure $3 D$. As shown by the figure, a robust signal for HA-ubiquitin was detected by Western blotting in cells (input lanes) expressing this construct and such global signal was increased in cells also expressing myc-Parkin. Additionally, a signal for ubiquitinated endophilin — a single band suggesting monoubiquitination-was observed selectively in anti-GFP immunoprecipitates generated from myc-Parkinexpressing cells (Fig. 3D).

To determine whether the Parkin-endophilin interaction also may result in the ubiquitination of the protein neighbors of endophilin, we further explored the potential ubiquitination of the two major endophilin binding partners, synaptojanin 1 and dynamin1, using the same system: HEK293T cells expressing myc-Parkin, HA-ubiquitin, and either GFP-synaptojanin 1 or dynamin1-GFP. As in the case of endophilin-GFP, only in the presence of Parkin, HA-positive bands consistent with monoubiquitination were detected by Western blotting in anti-GFP immunoprecipitates (Fig. 3E,F). A similar experiment per- formed with CLC-GFP did not result in HA-positive bands in the anti-GFP immunoprecipitates (Fig. $3 G$ ), confirming the specificity of the ubiquitination reaction for the two endophilin neighbors.

\section{Discussion}

The robust increase of Parkin level in the nervous system of endophilin mutant mice strikingly contrasts with the downregulation of several other neuronal and synaptic proteins. Such change, which our results suggest to be dependent on transcriptional regulation, reveals a new functional link between the two proteins, beyond their property to interact. As the binding of Parkin to endophilin results in the mono-ubiquitination of both endophilin and its major binding partners, dynamin and synaptojanin 1, Parkin may have a regulatory function on endophilin-containing endocytic protein complexes.

Our findings represent yet another piece of evidence indicating that proteins that participate in synaptic vesicle recycling are part of a protein network whose dysfunction leads to PD. Several reports have implicated LRRK2, which genetically and biochemically interacts with endophilin (Matta et al., 2012), in synaptic 
vesicle traffic (Shin et al., 2008; Piccoli et al., 2011, 2014; Yun et al., 2013). Three recent studies reported the occurrence in autosomal recessive juvenile-onset Parkinsonism of a homozygous loss-of-function missense mutation in the Sac1 domain of synaptojanin 1, the preferred interactor of endophilin at synapses and an enzyme involved in clathrin uncoating at synapses (Krebs et al., 2013; Quadri et al., 2013; Olgiati et al., 2014). Mutations within the DNAJC6 gene, which encodes auxilin, a protein that cooperates with endophilin and synaptojanin in the uncoating of endocytic clathrin-coated vesicles (Yim et al., 2010), have also been associated in autosomal recessive juvenile Parkinsonism (Edvardson et al., 2012; Köroglŭ et al., 2013). The auxilin paralog, GAK, was identified as a risk factor in PD (Pankratz et al., 2009), and recently another DNAJ domain-containing protein, DNAJC13/RME-8, which is involved in clathrin and retromermediated endosomal trafficking, has also been linked to PD (Vilarino-Guell et al., 2014). Finally, endophilin level is upregulated in mice lacking all three isoforms of synuclein, the first known PD protein (Westphal and Chandra, 2013). Major open questions remain concerning not only the mechanisms through which dysfunction of synaptic vesicle recycling gene leads to neurodegeneration, but also why such dysfunction leads to the selective neurological impairment characteristic of PD.

\section{References}

Chow CY, Zhang Y, Dowling JJ, Jin N, Adamska M, Shiga K, Szigeti K, Shy ME, Li J, Zhang X, Lupski JR, Weisman LS, Meisler MH (2007) Mutation of FIG4 causes neurodegeneration in the pale tremor mouse and patients with CMT4J. Nature 448:68-72. CrossRef Medline

Cremona O, Di Paolo G, Wenk MR, Lüthi A, Kim WT, Takei K, Daniell L, Nemoto Y, Shears SB, Flavell RA, McCormick DA, De Camilli P (1999) Essential role of phosphoinositide metabolism in synaptic vesicle recycling. Cell 99:179-188. CrossRef Medline

Dawson TM, Dawson VL (2010) The role of parkin in familial and sporadic Parkinson's disease. Mov Disord 25 [Suppl 1]:S32-S39. CrossRef Medline

de Heuvel E, Bell AW, Ramjaun AR, Wong K, Sossin WS, McPherson PS (1997) Identification of the major synaptojanin-binding proteins in brain. J Biol Chem 272:8710-8716. CrossRef Medline

Di Paolo G, Moskowitz HS, Gipson K, Wenk MR, Voronov S, Obayashi M, Flavell R, Fitzsimonds RM, Ryan TA, De Camilli P (2004) Impaired PtdIns(4,5)P2 synthesis in nerve terminals produces defects in synaptic vesicle trafficking. Nature 431:415-422. CrossRef Medline

Edvardson S, Cinnamon Y, Ta-Shma A, Shaag A, Yim YI, Zenvirt S, Jalas C, Lesage S, Brice A, Taraboulos A, Kaestner KH, Greene LE, Elpeleg O (2012) A deleterious mutation in DNAJC6 encoding the neuronalspecific clathrin-uncoating co-chaperone auxilin, is associated with juvenile parkinsonism. PLoS One 7:e36458. CrossRef Medline

Fallon L, Moreau F, Croft BG, Labib N, Gu WJ, Fon EA (2002) Parkin and CASK/LIN-2 associate via a PDZ-mediated interaction and are colocalized in lipid rafts and postsynaptic densities in brain. J Biol Chem 277:486-491. CrossRef Medline

Fallon L, Bélanger CM, Corera AT, Kontogiannea M, Regan-Klapisz E, Moreau F, Voortman J, Haber M, Rouleau G, Thorarinsdottir T, Brice A, van Bergen En Henegouwen PM, Fon EA (2006) A regulated interaction with the UIM protein Eps15 implicates parkin in EGF receptor trafficking and PI(3)K-Akt signalling. Nat Cell Biol 8:834-842. CrossRef Medline

Ferguson SM, Brasnjo G, Hayashi M, Wolfel M, Collesi C, Giovedi S, Raimondi A, Gong LW, Ariel P, Paradise S, O’toole E, Flavell R, Cremona O, Miesenböck G, Ryan TA, De Camilli P (2007) A selective activitydependent requirement for dynamin 1 in synaptic vesicle endocytosis. Science 316:570-574. CrossRef Medline

Goldberg MS, Fleming SM, Palacino JJ, Cepeda C, Lam HA, Bhatnagar A, Meloni EG, Wu N, Ackerson LC, Klapstein GJ, Gajendiran M, Roth BL, Chesselet MF, Maidment NT, Levine MS, Shen J (2003) Parkindeficient mice exhibit nigrostriatal deficits but not loss of dopaminergic neurons. J Biol Chem 278:43628-43635. CrossRef Medline

Hayashi M, Raimondi A, O’Toole E, Paradise S, Collesi C, Cremona O, Fer- guson SM, De Camilli P (2008) Cell- and stimulus-dependent heterogeneity of synaptic vesicle endocytic recycling mechanisms revealed by studies of dynamin 1-null neurons. Proc Natl Acad Sci U S A 105:21752180. CrossRef Medline

Huynh DP, Scoles DR, Nguyen D, Pulst SM (2003) The autosomal recessive juvenile Parkinson disease gene product, parkin, interacts with and ubiquitinates synaptotagmin XI. Hum Mol Genet 12:2587-2597. CrossRef Medline

Joch M, Ase AR, Chen CX, MacDonald PA, Kontogiannea M, Corera AT, Brice A, Séguéla P, Fon EA (2007) Parkin-mediated monoubiquitination of the PDZ protein PICK1 regulates the activity of acid-sensing ion channels. Mol Biol Cell 18:3105-3118. CrossRef Medline

Köroglŭ Ç, Baysal L, Cetinkaya M, Karasoy H, Tolun A (2013) DNAJC6 is responsible for juvenile parkinsonism with phenotypic variability. Parkinsonism Relat Disord 19:320-324. CrossRef Medline

Krebs CE, Karkheiran S, Powell JC, Cao M, Makarov V, Darvish H, Di Paolo G, Walker RH, Shahidi GA, Buxbaum JD, De Camilli P, Yue Z, PaisánRuiz C (2013) The Sacl domain of SYNJ1 identified mutated in a family with early-onset progressive Parkinsonism with generalized seizures. Hum Mutat 34:1200-1207. CrossRef Medline

Matta S, Van Kolen K, da Cunha R, van den Bogaart G, Mandemakers W, Miskiewicz K, De Bock PJ, Morais VA, Vilain S, Haddad D, Delbroek L, Swerts J, Chávez-Gutiérrez L, Esposito G, Daneels G, Karran E, Holt M, Gevaert K, Moechars DW, De Strooper B, et al. (2012) LRRK2 controls an EndoA phosphorylation cycle in synaptic endocytosis. Neuron 75 : 1008-1021. CrossRef Medline

Milosevic I, Giovedi S, Lou X, Raimondi A, Collesi C, Shen H, Paradise S, O’Toole E, Ferguson S, Cremona O, De Camilli P (2011) Recruitment of endophilin to clathrin-coated pit necks is required for efficient vesicle uncoating after fission. Neuron 72:587-601. CrossRef Medline

Olgiati S, De Rosa A, Quadri M, Criscuolo C, Breedveld GJ, Picillo M, Pappatà S, Quarantelli M, Barone P, De Michele G, Bonifati V (2014) PARK20 caused by SYNJ1 homozygous Arg258Gln mutation in a new Italian family. Neurogenetics 15:183-188. CrossRef Medline

Pankratz N, Wilk JB, Latourelle JC, DeStefano AL, Halter C, Pugh EW, Doheny KF, Gusella JF, Nichols WC, Foroud T, Myers RH (2009) Genomewide association study for susceptibility genes contributing to familial Parkinson disease. Hum Genet 124:593-605. CrossRef Medline

Piccoli G, Onofri F, Cirnaru MD, Kaiser CJ, Jagtap P, Kastenmüller A, Pischedda F, Marte A, von Zweydorf F, Vogt A, Giesert F, Pan L, Antonucci F, Kiel C, Zhang M, Weinkauf S, Sattler M, Sala C, Matteoli M, Ueffing M, et al. (2014) LRRK2 binds to neuronal vesicles through protein interactions mediated by its C-terminal WD40 domain. Mol Cell Biol 34:21472161. CrossRef Medline

Piccoli G, Condliffe SB, Bauer M, Giesert F, Boldt K, De Astis S, Meixner A, Sarioglu H, Vogt-Weisenhorn DM, Wurst W, Gloeckner CJ, Matteoli M, Sala C, Ueffing M (2011) LRRK2 controls synaptic vesicle storage and mobilization within the recycling pool. J Neurosci 31:2225-2237. CrossRef Medline

Quadri M, Fang M, Picillo M, Olgiati S, Breedveld GJ, Graafland J, Wu B, Xu F, Erro R, Amboni M, Pappatà S, Quarantelli M, Annesi G, Quattrone A, Chien HF, Barbosa ER, Oostra BA, Barone P, Wang J, Bonifati V (2013) Mutation in the SYNJ1 gene associated with autosomal recessive, early-onset Parkinsonism. Hum Mutat 34:1208-1215. CrossRef Medline

Ringstad N, Nemoto Y, De Camilli P (1997) The SH3p4/Sh3p8/SH3p13 protein family: binding partners for synaptojanin and dynamin via a Grb2-like Src homology 3 domain. Proc Natl Acad Sci U S A 94:85698574. CrossRef Medline

Schuske KR, Richmond JE, Matthies DS, Davis WS, Runz S, Rube DA, van der Bliek AM, Jorgensen EM (2003) Endophilin is required for synaptic vesicle endocytosis by localizing synaptojanin. Neuron 40:749-762 CrossRef Medline

Shimura H, Hattori N, Kubo Si, Mizuno Y, Asakawa S, Minoshima S, Shimizu N, Iwai K, Chiba T, Tanaka K, Suzuki T (2000) Familial Parkinson disease gene product, parkin, is a ubiquitin-protein ligase. Nat Genet 25: 302-305. CrossRef Medline

Shin N, Jeong H, Kwon J, Heo HY, Kwon JJ, Yun HJ, Kim CH, Han BS, Tong Y, Shen J, Hatano T, Hattori N, Kim KS, Chang S, Seol W (2008) LRRK2 regulates synaptic vesicle endocytosis. Exp Cell Res 314:2055-2065. CrossRef Medline 
Trempe JF, Chen CX, Grenier K, Camacho EM, Kozlov G, McPherson PS, Gehring K, Fon EA (2009) SH3 domains from a subset of BAR proteins define a Ubl-binding domain and implicate parkin in synaptic ubiquitination. Mol Cell 36:1034-1047. CrossRef Medline

Verstreken P, Koh TW, Schulze KL, Zhai RG, Hiesinger PR, Zhou Y, Mehta SQ, Cao Y, Roos J, Bellen HJ (2003) Synaptojanin is recruited by endophilin to promote synaptic vesicle uncoating. Neuron 40:733-748. CrossRef Medline

Vilarino-Guell C, Rajput A, Milnerwood AJ, Shah B, Szu-Tu C, Trinh J, Yu I, Encarnacion M, Munsie LN, Tapia L, Gustavsson EK, Chou P, Tatarnikov I, Evans DM, Pishotta FT, Volta M, Beccano-Kelly D, Thompson C, Lin MK, Sherman HE, et al. (2014) DNAJC13 mutations in Parkinson disease. Hum Mol Genet 23:1794-1801. CrossRef Medline

Westphal CH, Chandra SS (2013) Monomeric synucleins generate membrane curvature. J Biol Chem 288:1829-1840. CrossRef Medline

Yim YI, Sun T, Wu LG, Raimondi A, De Camilli P, Eisenberg E, Greene LE
(2010) Endocytosis and clathrin-uncoating defects at synapses of auxilin knock-out mice. Proc Natl Acad Sci U S A 107:4412-4417. CrossRef Medline

Yun HJ, Park J, Ho DH, Kim H, Kim CH, Oh H, Ga I, Seo H, Chang S, Son I, Seol W (2013) LRRK2 phosphorylates Snapin and inhibits interaction of Snapin with SNAP-25. Exp Mol Med 45:e36. CrossRef Medline

Zhang Y, Gao J, Chung KK, Huang H, Dawson VL, Dawson TM (2000) Parkin functions as an E2-dependent ubiquitin- protein ligase and promotes the degradation of the synaptic vesicle-associated protein, CDCrel-1. Proc Natl Acad Sci U S A 97:13354-13359. CrossRef Medline

Zhang Y, Zolov SN, Chow CY, Slutsky SG, Richardson SC, Piper RC, Yang B, Nau JJ, Westrick RJ, Morrison SJ, Meisler MH, Weisman LS (2007) Loss of Vac14, a regulator of the signaling lipid phosphatidylinositol 3,5bisphosphate, results in neurodegeneration in mice. Proc Natl Acad Sci U S A 104:17518-17523. CrossRef Medline 